\title{
Information Literacy in New Zealand Secondary and Primary Schools
}

\section{HELEN SLYFIELD}

\author{
National Library of New Zealand, \\ Wellington, \\ New Zealand \\ helenslyfield@natlib.govt.nz
}

\begin{abstract}
New Zealand schools were surveyed on current aspects of developing information literacy. The research also sought to identify schools' priorities to further develop these skills. Response rates were 63\% (secondary schools) and $67 \%$ (primary schools).

Most schools are working on various aspects of teaching information skills and considered their students are developing these skills to at least some extent but recognise that there is still some way to go.

Research showed a strong need for professional development for teachers and for information literacy resources covering the place of information skills in the curriculum, a skills framework at each level, and practical help for teaching and evaluating information skills.
\end{abstract}

\section{INTRODUCTION}

This research project describes what was happening in 2000 with information literacy in New Zealand schools and what schools considered they needed to further develop information literacy.

The National Library has undertaken this research as a step in achieving its own goals, in particular its advice goal "To be a key adviser to Government on the role of information in New Zealand's cultural and economic life") and its Schools goal ("To ensure all schools have tools to use and manage information effectively in support of the teaching of the New Zealand curriculum.". The current Strategic Plan supports these goals through specific timebound objectives that are built into business planning. Current objectives that relate to information literacy are:

- Establish a policy for information literacy within New Zealand;

- Establish a policy for equitable access to information for people within New Zealand;

- Establish strategies to meet the needs of targeted schools;

- Identify future needs for information provision and use in the education environment. 
The Schools Services Business Plan also has two relevant objectives:

- To identify services and products which can be provided by the National Library to support schools in developing information literacy;

- To identify any variations in needs of different types of schools, eg primary and secondary, small schools, rural schools.

A recent report noted:

The nature of a 'desirable' education for employment is also likely to change. ... A desirable education ... is likely to involve a high level of literacy in the broadest sense (i.e. including not just the ability to read and write, but the ability to find, interpret and use information), as well as an education directed at how-to-learn skills. Education and training are increasingly being seen as life-long processes ... (New Zealand Government, 2001, p14).

In July 2000, a Forum on Information Literacy was held in Wellington with representatives from the education, library, government and business sectors to identify the next steps towards increasing the development of information literacy skills among New Zealanders. Participants in the forum suggested that research be carried out to describe what is happening in schools and to identify what schools need to support them in developing information literacy in their students.

The research was undertaken to ensure that policies and strategies are strongly related to the current situation and expressed needs of teachers and librarians. It complements other research such as the 1999 survey of National Library advisers and centre managers on their views of information literacy in schools, qualitative action research on teaching problem solving and professional development of teachers in primary schools (Moore, 1999, 2000), and research on information literacy in public libraries which is currently being undertaken by LIANZA.

\section{METHOD}

\section{Definition of Information Literacy}

The definition used in the study was the one from the National Library Strategic Plan:

"locating, evaluating, managing, and using information [effectively] from a range of sources for problem solving, decision making and research" (p19).

\section{Questionnaire Development}

The survey was intended to obtain information in two main areas, namely, the current situation regarding information literacy in schools and identifying what schools consider they need to develop information literacy skills.

A draft questionnaire was produced and trialled with staff from primary and secondary schools and with National Library staff. 
The questionnaire stated that the New Zealand Curriculum Framework gives five specific information skills areas (p18), namely,

- Identify, locate, gather, store, retrieve, and process information from a range of sources;

- Organise, analyse, synthesize, evaluate, and use information;

- Present information clearly, logically, concisely, and accurately;

- Identify, describe, and interpret different points of view, and distinguish fact from opinion;

- Use a range of information-retrieval and information-processing technologies confidently and competently.

It also noted that the detailed curriculum documents for the essential learning areas include some information skills although they use different approaches and terms such as the investigation approach in science, inquiry method in social studies, and processing information in English.

The final version of the questionnaire included:

- Actions taken by schools regarding information literacy;

- Where information literacy is included in the curriculum and models used,

- Assessment of information literacy skills,

- Extent of achievement in the five areas of information skills specified in the NZ Curriculum Framework

- Satisfaction with various aspects of information skills teaching,

- Professional development relating to information literacy undertaken by teachers

- Barriers to effective teaching of information skills

- Sources of help to facilitate development of information literacy.

\section{Sample}

Two separate random samples were drawn, consisting of one fifth of primary schools (sample error $4 \%$ ) and one third of secondary schools (sample error $7 \%$ ). Code numbers were provided to ensure confidentiality.

\section{Administration and response rates}

The sampled schools (553) were sent the questionnaire on 4 September 2000. The questionnaires were addressed to principals with a suggestion that they might wish to consult others in the school who have knowledge across the curriculum such as the curriculum committee, curriculum coordinator, teacher librarian, librarian, ICT coordinator. A freepost envelope was provided in which to return the questionnaire. 
Schools which had not responded by the requested return date of 22 September were sent a reminder letter with the offer of another questionnaire if they had mislaid the first one. The response from primary schools was still relatively low by mid-October, and so nonresponding schools were telephoned and encouraged to complete the questionnaire. It was thought possible that schools might not have responded because they felt they were not doing very much in this area but only one of the principals contacted by telephone said this. Most talked about how busy they were or about other more immediate priorities. Four were new principals who did not know what had been happening in this area.

Eventually, replies were received from 70 secondary schools and 296 primary schools, giving response rates of $63 \%$ and $67 \%$ respectively.

Amongst secondary schools, response rates were a little lower for schools in the second to smallest quartile (59\%), for the largest schools (59\%), for low decile schools $(57 \%)$, for high decile schools $(59 \%)$, and for schools which had not participated in the Focus Programme for school library development (59\%).

Among primary schools, response rates were lower for the second to smallest quartile of schools $(62 \%)$, for low decile schools $(60 \%)$, and for schools which had not participated in the Focus Programme (58\%).

As described later, the school demographic variables tended to not be related in any systematic way to responses to most questions. One exception was that low decile schools tended to give a lower rating to the achievements of their students. This means that the overall rating of achievement in information literacy may be over-estimated. Another exception was that schools participating in the Focus Programme tended to be working on more actions relating to information literacy. As these schools had a higher response rate, the percentages of schools working on these actions reported here may be higher than the actual percentage.

The secondary school questionnaire was completed by the teacher with library responsibility (in $50 \%$ of schools), the principal (31\%), the curriculum coordinator/ committee $(24 \%)$, library staff $(21 \%)$ or someone else $(13 \%)^{1}$.

The primary questionnaire was completed by the principal (56\%), the teacher with library responsibility (38\%), the curriculum coordinator/committee (18\%), library staff $(6 \%)$, or someone else $(8 \%)$.

\section{Demographic Data}

The Ministry of Education provided current demographic data for schools at 1 March 2000. The information provided included type of school, number of students and decile (a measure of socio-economic advantage of students enrolled). Schools provided information on location.

\footnotetext{
${ }^{1}$ Percentages do not add to 100 because questionnaires could be completed by more than one person.
} 


\section{Use of National Library Services}

The National Library had information about whether the school had participated in the Focus Programme, number of advisory service contacts, and issues from the Curriculum Information Service (CIS). The latter measures covered the time period 1 January to 1 August, 2000.

\section{OVERVIEW AND DISCUSSION}

\section{Actions Relating to the Teaching of Information Skills}

Almost all schools (97\% secondary, 98\% primary) reported having undertaken at least one action relating to teaching information skills. Generally, these actions were underway rather than in place.

\section{Table 1}

\section{Actions Relating to Teaching Information Literacy (\% of Schools having} Actions in Place or in Process)

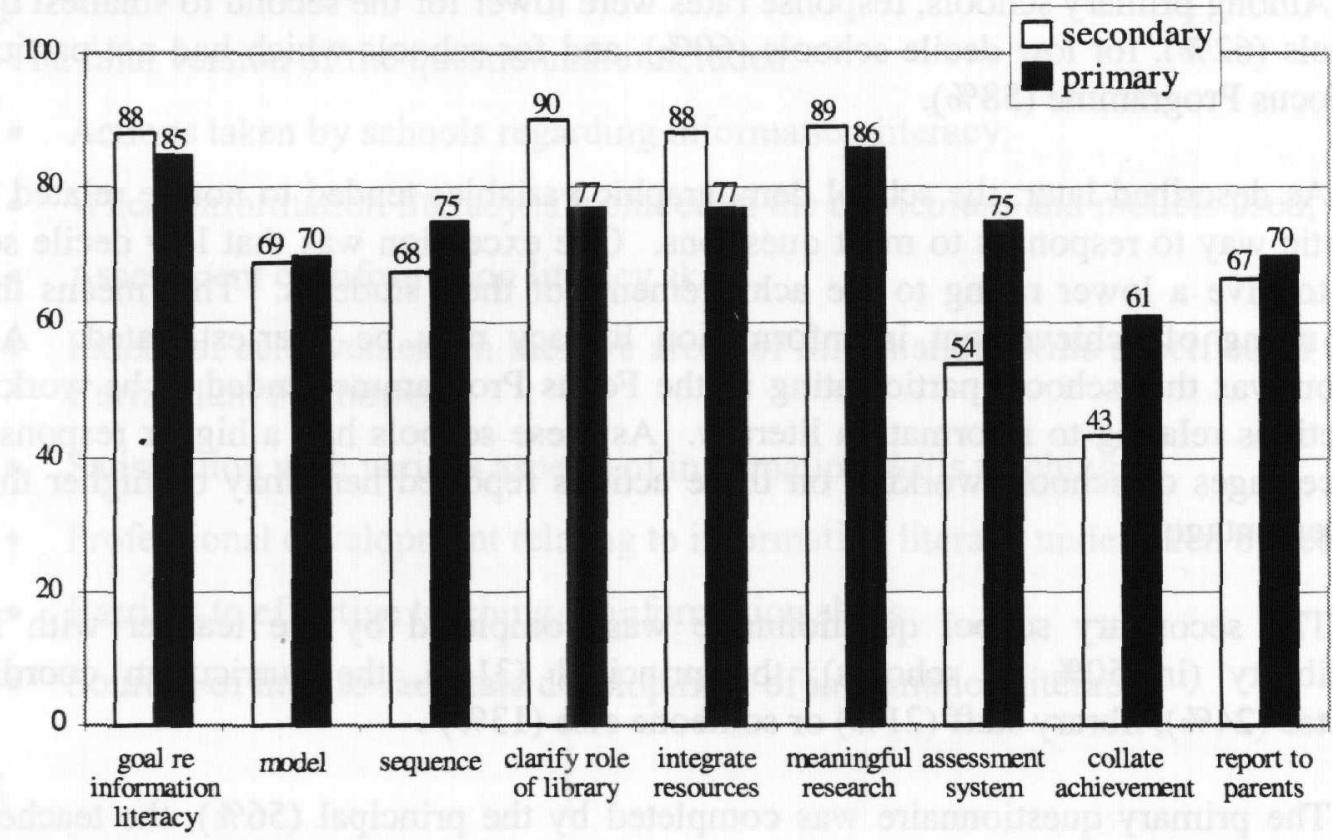

As Table 1 shows these included:

- including a goal or objective relating to information skills in the school/library strategic plan ( $88 \%$ secondary, $85 \%$ primary);

- discussing a model and terminology to be used across the school $(69 \%, 70 \%)$;.

- identifying the range and sequence of skills to be achieved at each level $(68 \%$, $76 \%$ );

- clarifying the role of the school library collection in supporting the development of information skills $(90 \%, 77 \%)$;

- developing a plan to integrate resources to develop students' ability to evaluate, select, interpret, manipulate and present information $(88 \%, 77 \%)$; 
- identifying strategies to make research more meaningful by ensuring there are learning outcomes in both information skills and curriculum content $(89 \%, 86 \%)$.

Client satisfaction surveys carried out by the National Library support the finding that many schools are undertaking actions relating to information literacy. The client surveys between 1998 and 2000 found that two thirds of focus schools had been working on developing an information literacy programme and planning strategies to integrate the library's role in developing essential skills through learning areas. Four percent or fewer said work in these areas was not needed. A survey of random samples of schools in found that just over half were planning for the development of information literacy as a result of their involvement with National Library advisory services.

\section{Teaching of information skills}

The reliability of responses to the questions on the teaching of information skills will vary according to how knowledgeable the respondent is about what various teachers in the school are doing in regard to information skills. It is probably more difficult for respondents in secondary schools and larger schools to have this knowledge across the school.

Respondents were more knowledgeable about where in the curriculum information skills were taught, than about the models used and how skills were assessed. Secondary school respondents were more likely than primary school respondents to say they did not know. The percentages of respondents who said they did not know where in the curriculum information skills was taught was 5\% or less for the main curriculum areas and up to $16 \%$ for health and PE and "Other". In many of the schools surveyed, respondents indicated they did not know whether a particular model had been used, particularly the Big Six (Eisenberg and Bertowitz, 1998) model (68\% secondary, $41 \%$ primary). Between $14 \%$ and $25 \%$ of schools did not know whether teachers used the Action Learning (Gawith, 1998) model or a school-developed model.

\section{Table 2}

\section{Where Information Skills are taught in the Curriculum (\% of Schools to a great extent or to some extent)}

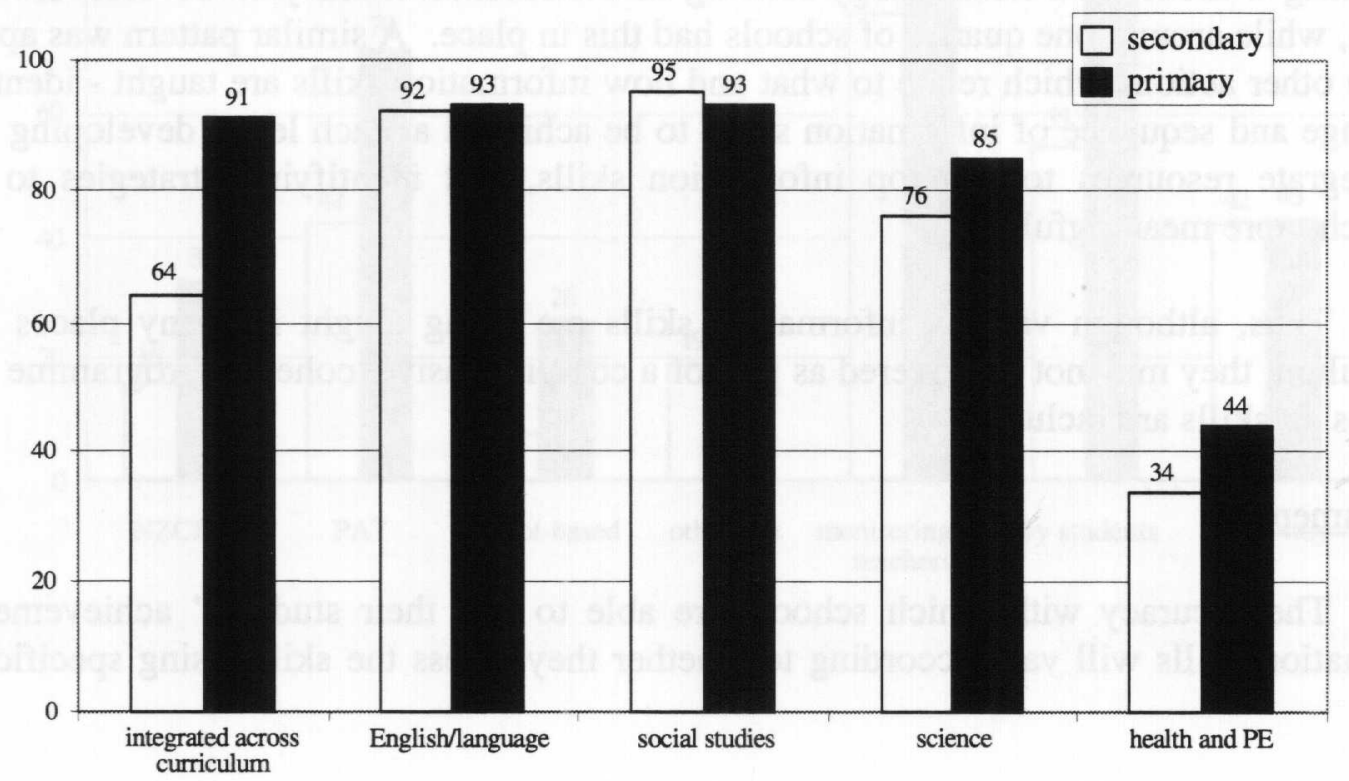


A substantial majority of schools indicated they were teaching information skills to at least some extent in each of these three curriculum areas - English, social studies, and science. Almost all primary schools $(91 \%)$ and a majority of secondary schools (64\%) said the teaching of information skills was integrated across the curriculum (see Table 2).

Although most schools were teaching information skills in each curriculum area, there seemed to be a wide variety of ways of teaching it (see Table 3). The Action Learning model was used by at least a few teachers in $78 \%$ of secondary schools and $70 \%$ of primary schools. However, only $10 \%$ of secondary schools and $23 \%$ of primary schools reported that all or most teachers used this model. A school-developed model was used by at least a few teachers in $39 \%$ of secondary and $50 \%$ of primary schools.

\section{Table 3}

\section{Models of Information Skills Used (\% of Schools with at least some Teachers Using)}

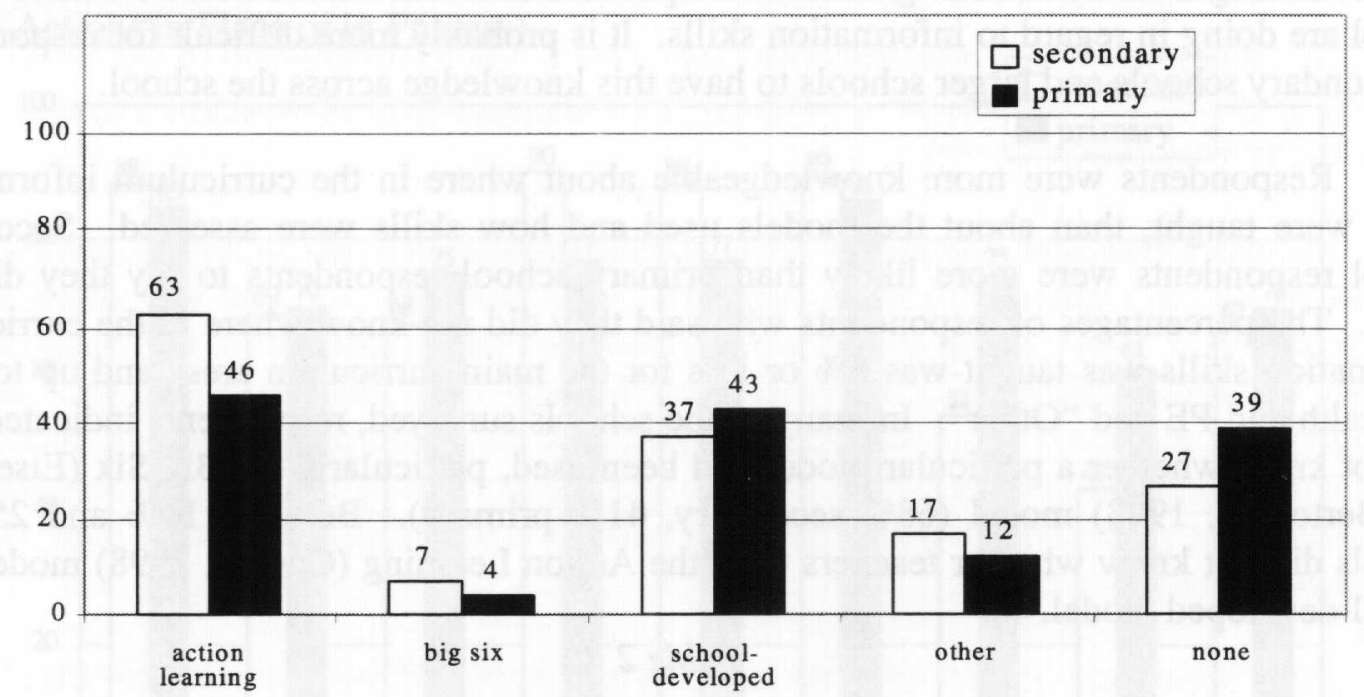

This is consistent with the finding that around half the schools were in the process of discussing a model and terminology relating to information literacy to be used across the school, while around one quarter of schools had this in place. A similar pattern was apparent for the other actions which relate to what and how information skills are taught - identifying the range and sequence of information skills to be achieved at each level, developing a plan to integrate resources to develop information skills, and identifying strategies to make research more meaningful.

Thus, although various information skills are being taught in many places in the curriculum, they may not be covered as part of a comprehensive, coherent programme which ensures all skills are included.

\section{$\underline{\text { Assessment }}$}

The accuracy with which schools are able to rate their students' achievements in information skills will vary according to whether they assess the skills using specific tests; 
and how knowledgeable teachers are about these skills. An ERO report on assessment in primary schools (1999) noted "Teachers in many schools have records of a large number of assessments of learning objectives or statements of outcome for many areas of the curriculum for each child." ERO reported that in many schools student achievement is assessed on a variety of dimensions according to teacher judgement. "The processes of assessment used and the things assessed make it unlikely that many of the records would be of the quality desirable for the basis of conclusions about the standards achieved or the progress made by a student." (p3, online version).

Information from this study suggests that these statements would be applicable to the assessment of information skills. Only $9 \%$ of secondary schools and $23 \%$ of primary schools had in place an assessment system to enable teachers to track students' progress in information skills. Similarly, only $8 \%$ of secondary and $14 \%$ of primary schools had collated assessment information to measure school-wide achievement. Around half the schools were in the process of establishing an assessment system $(45 \%, 52 \%)$, and $35 \%$ of secondary and $47 \%$ of primary schools were in the process of collating assessment information. This suggests that respondents may not have had an objective basis for responding to the question on achievements in information skills.

A majority of schools reported that at least some teachers monitored these skills (76\% secondary, $91 \%$ primary) or that students assessed themselves $(55 \%, 80 \%)$ (see Table 4). These results seem consistent with the report to the Ministry of Education on assessment practices in primary schools, the range of practices used by the teachers included tests; pre and post tests; conferencing with students; cumulative records; self-assessment; and portfolios. (p 11, On-line version).

\section{Table 4}

\section{Ways Information Skills are Assessed (\% of Schools with at least some Teachers using)}

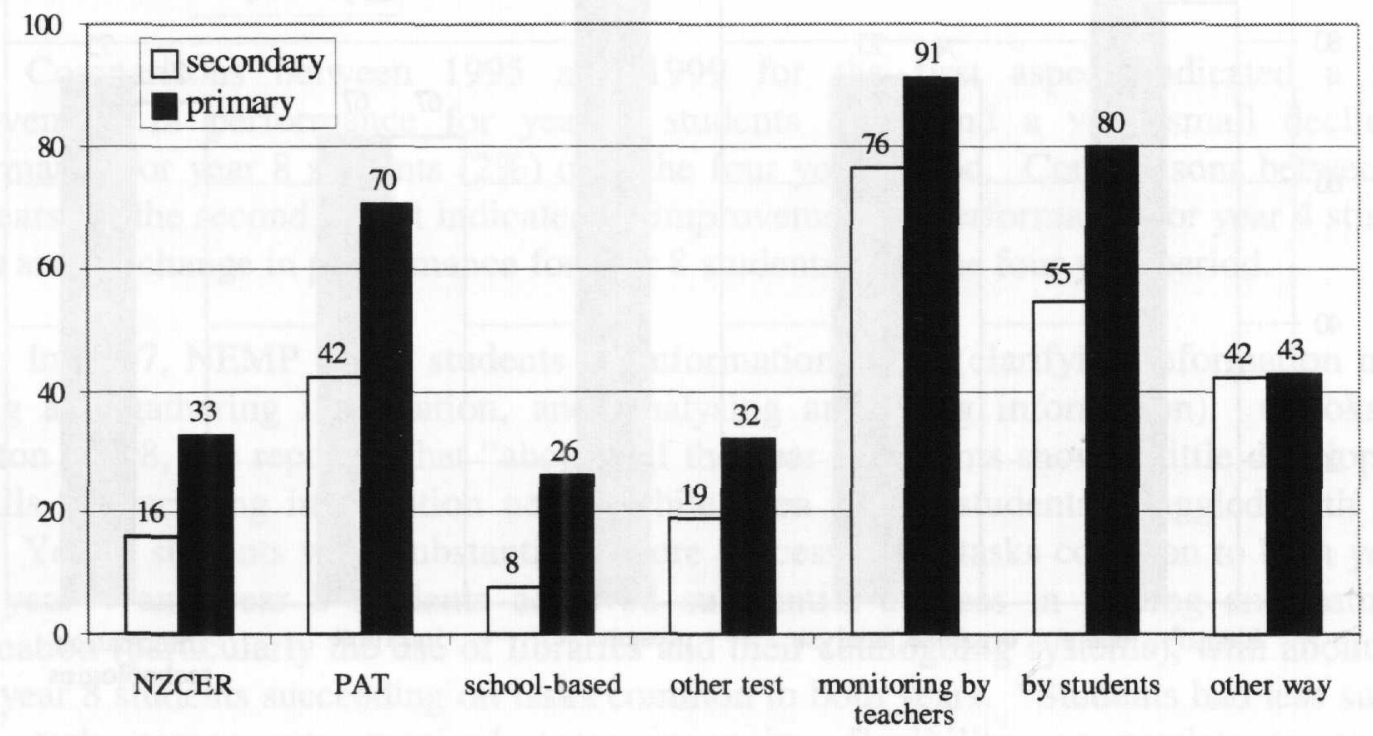


The PAT study skills tests (Reid et al, 1969) were used by at least some teachers in $42 \%$ of secondary schools and $70 \%$ of primary schools. (These tests cover Knowledge and Use of Reference Materials (years 5 to 11); Reading maps, graphs, tables and diagrams (years 5-11); and Reading study skills (years 7-11). The first includes use of encyclopedias, dictionaries, directories, tables of contents, indexes, library catalogues, and using books to locate information. The third includes location skimming, deriving information quickly from a printed page, summarising, outlining, relevance to topic, and differentiating between fact and opinion.) Use of the NZCER information literacy tests was lower (16\% secondary and 33\% primary) and reflects the fact that the tests became available for sale during 2000 . Some schools used various other tests $(19 \%$, $32 \%)$, and some developed their own tests $(8 \%, 26 \%)$.

\section{Achievement}

At least two thirds of both secondary and primary schools considered that students were achieving to at least some extent in each of the five specific information skills areas named in the New Zealand Curriculum Framework. Schools felt students were achieving to a greater extent in the areas: "identify, locate, gather, store, retrieve, and process information from a range of sources" ( $85 \%$ secondary, $87 \%$ primary to at least some extent), and "present information clearly, logically, concisely, and accurately" $(87 \%, 87 \%)$ (see Tables 5 and 6). The area where schools felt there was the lowest level of achievement was "identify, describe, and interpret different points of view, and distinguish fact from opinion.

\section{Table 5}

\section{Achievement by Students in each of the Five Specific Information Skills Areas (\% of Schools to at least some extent)}

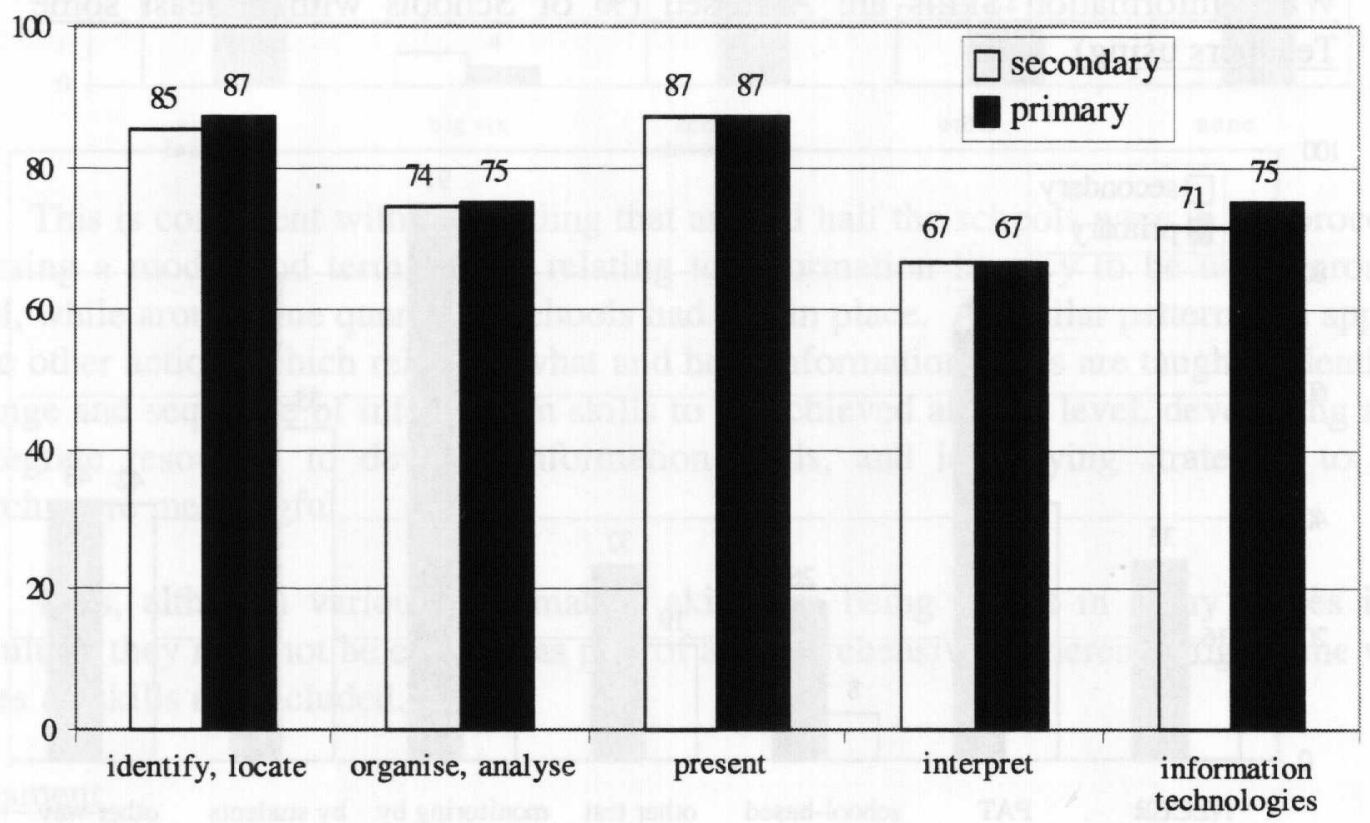

In most cases, schools felt students were achieving to some extent rather than to a great extent. 
Table 6

\section{Achievement by Students in each of the Five Specific Information Skills Areas (\% of Schools to a great extent)}

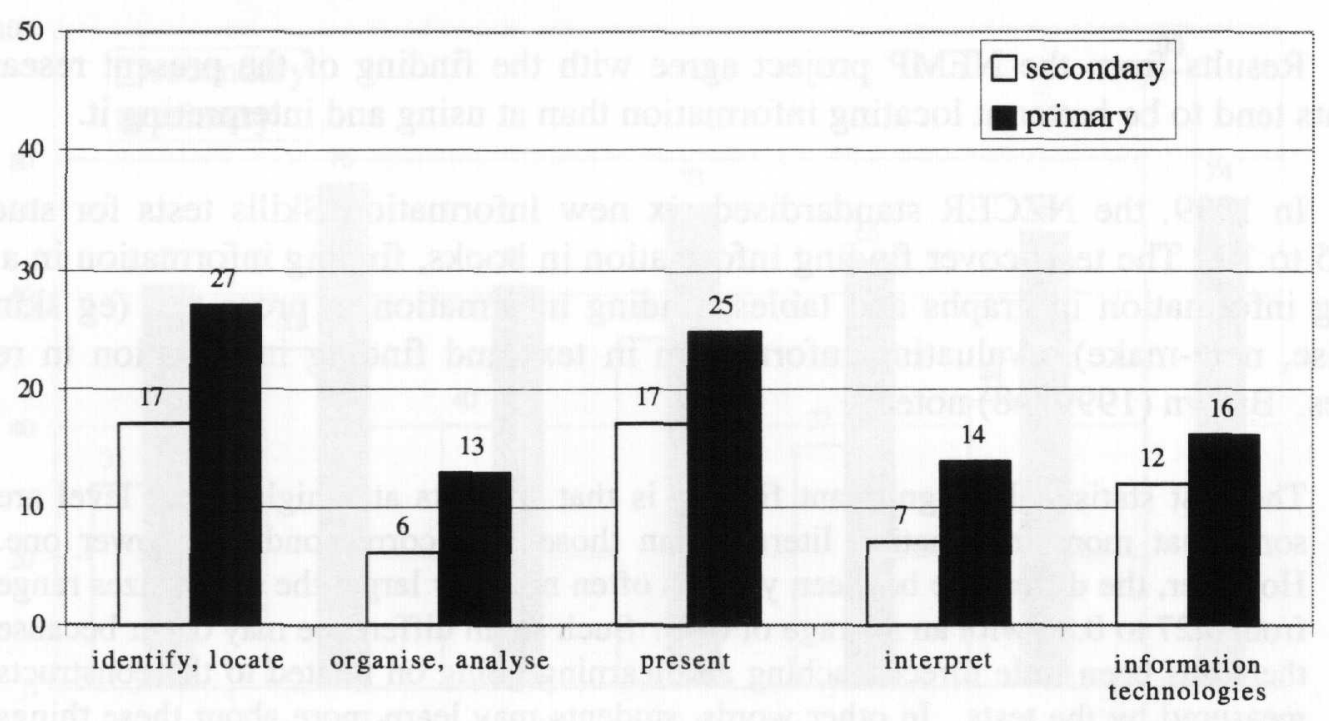

These results seem to be comparable to those from the National Education Monitoring Project (NEMP) and from the new information literacy tests produced by New Zealand Council for Educational Research (NZCER).

The NEMP has investigated two aspects of information skills. In 1995 and 1999, NEMP tested students on graphs, tables and maps. The 1999 report (Crooks and Flockton, 1999, pp4-5) notes that averaged across 63 task components focused on extracting and interpreting information and 33 task components focused on constructing or completing graphs, tables and maps, "students have made substantial progress between year 4 and year 8 in the skills assessed by these tasks."

Comparisons between 1995 and 1999 for the first aspect indicated a small improvement in performance for year 4 students $(3 \%)$ and a very small decline in performance for year 8 students (2\%) over the four year period. Comparisons between the two years for the second aspect indicated an improvement in performance for year 4 students (12\%) and no change in performance for year 8 students over the four year period.

In 1997, NEMP tested students on information skills (clarifying information needs, finding and gathering information, and, analysing and using information). Crooks and Flockton $(1998, \mathrm{p} 4)$ reported that "about half the year 4 students showed little development of skills in clarifying information needs, while even year 8 students struggled with some tasks. Year 8 students were substantially more successful on tasks common to both years." Both year 4 and year 8 students achieved substantial success in finding and gathering information (particularly the use of libraries and their cataloguing systems), with about $25 \%$ more year 8 students succeeding on tasks common to both years. "Students had less success where task components required some ingenuity, flexibility, or persistence to find appropriate search keywords or routes" ... and when asked to interpret or summarise 
information. Again, about $25 \%$ more year 8 students succeeded on tasks common to both year levels. Information skills will be tested for a second time in 2001. A comparison of the 2001 results with those from 1997 will provide information about whether there has been an improvement in the level of achievement of year 4 and year 8 students over the four years.

Results from the NEMP project agree with the finding of the present research that students tend to be better at locating information than at using and interpreting it.

In 1999, the NZCER standardised six new Information Skills tests for students in years 5 to 10. The tests cover finding information in books, finding information in a library, finding information in graphs and tables, finding information in prose test (eg skim, scan, organise, note-make), evaluating information in text and finding information in reference sources. Brown $(1999, \mathrm{p} 8)$ noted:

The first statistically significant finding is that students at a higher year level are somewhat more information literate than those at a correspondingly lower one. However, the difference between years is often not very large; the effect sizes range from 0.27 to 0.86 with an average of 0.45 . Such small difference may occur because there has been little direct teaching and learning going on related to the constructs measured by the tests. In other words, students may learn more about these things incidentally rather than as a result of deliberate instructional programmes.

Low decile schools tended to give a lower rating to the achievements of their students. The NEMP project and Brown (1999) also reported this situation. This result is to be expected as the schools are allocated to decile on the basis of their student intake having many of the socio-economic factors associated with lower school achievement.

\section{Satisfaction with current aspects of teaching information skills}

How satisfied schools are may depend on how much they know about information skills and/or information literacy. Primary schools where staff had undertaken professional development relating to information literacy tended to be more satisfied with current aspects of teaching information skills. The opposite pattern held for secondary schools. Both primary and secondary schools which had more contacts with National Library advisory services tended to be less satisfied. Secondary schools which had participated in the Focus Programme tended to be less satisfied while responses from primary schools which had participated in the Focus Programme showed no consistent pattern.

This may indicate that involvement with the Focus Programme and National Library advisory services (which include a wide range of topics about library development and management as well as information literacy) raises awareness about information skills which leads to schools feeling less satisfied with their current situation. However, professional development specifically related to information literacy leads to schools feeling more confident about teaching information skills.

In this study, primary schools tended to be more satisfied than secondary schools with each of six current aspects of teaching information skills. Between $61 \%$ and $76 \%$ of primary schools were very satisfied or satisfied with each aspect compared with $31 \%$ to 53\% of secondary schools. 
Table 7

Satisfaction with Current Aspects of Teaching Information Skills (\% of Schools very satisfied or satisfied)

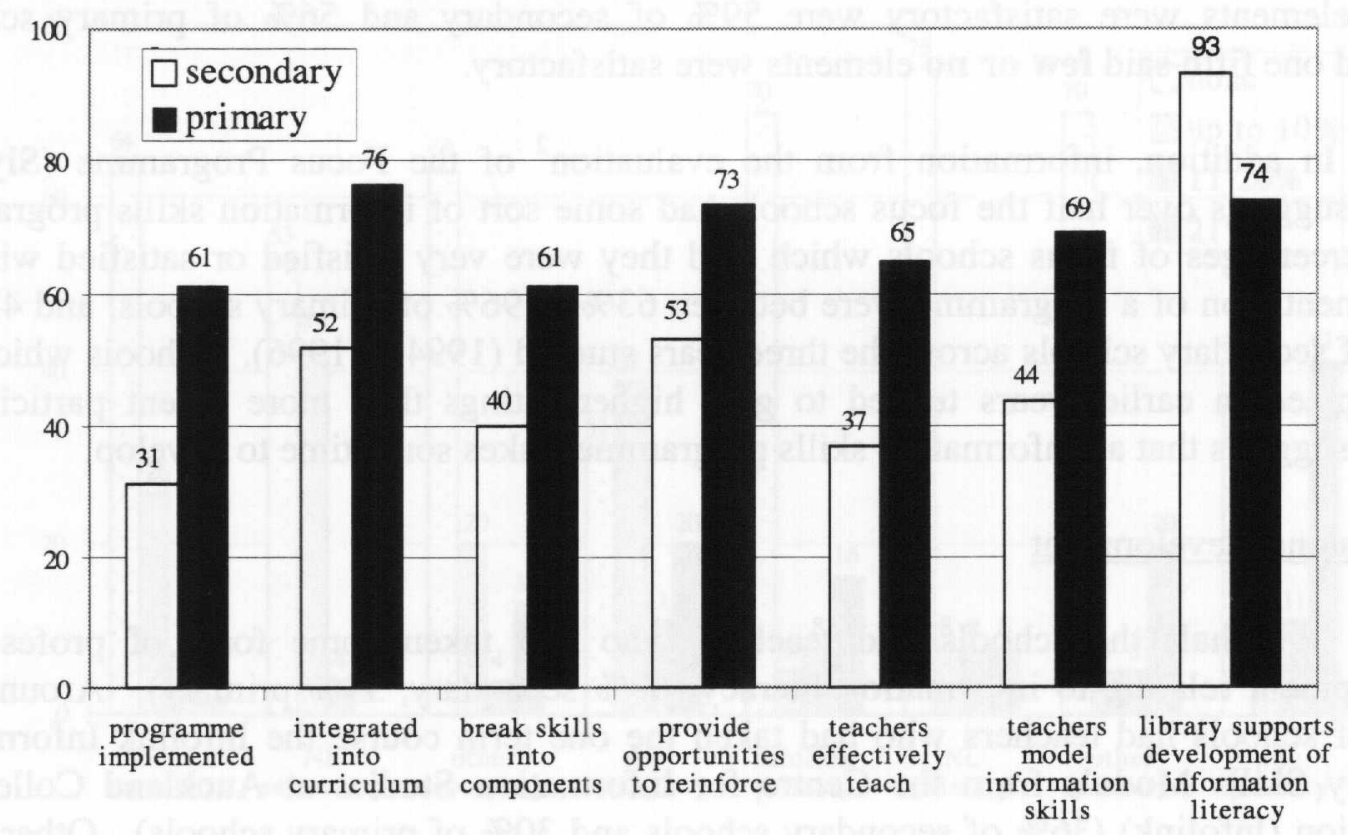

Satisfaction was higher for general aspects such as information skills teaching being integrated into the curriculum ( $52 \%$ secondary, $76 \%$ primary) and many opportunities being provided to reinforce students' use of information skills $(53 \%, 73 \%)$ (see Table 7 ).

Satisfaction tended to be lower for aspects requiring more specific knowledge of information skills and how to teach it:

- Teachers have the knowledge and skills to effectively teach information skills (37\% secondary, $65 \%$ primary);

- Teachers break down skills into specific components to ensure students are taught these skills $(40 \%, 61 \%)$;

- Teachers model the use of information skills to their students $(44 \%, 69 \%)$;

- Information skills programme has been implemented across the school (31\%, $61 \%)$.

These results are consistent with Moore's indepth study (1999) of four primary schools which found that "Most teachers believed they had a 'practical understanding' of information skills, but again around half of them then responded that they were unfamiliar with ways in which the process of finding and using information could be broken into steps for teaching."

They are also consistent with the finding that a majority of schools were still working on actions relating to practical aspects of teaching information skills. 
A survey of random samples of secondary and primary schools about their school libraries (Slyfield, 2001, in preparation) showed that around one fifth considered all or most aspects of information literacy (eg staff professional development, information skills matrix, information skills programme) in their school to be satisfactory. The percentages saying some elements were satisfactory were $59 \%$ of secondary and $56 \%$ of primary schools. Around one fifth said few or no elements were satisfactory.

In addition, information from the evaluation ${ }^{2}$ of the Focus Programme (Slyfield, 1999) suggests over half the focus schools had some sort of information skills programme. The percentages of focus schools which said they were very satisfied or satisfied with the implementation of a programme were between $63 \%$ to $96 \%$ of primary schools, and $43 \%$ to $75 \%$ of secondary schools across the three years studied (1994 to 1996). Schools which had participated in earlier years tended to give higher ratings than more recent participants, which suggests that an information skills programmes takes some time to develop.

\section{Professional development}

Over half the schools had teachers who had taken some form of professional development relating to information literacy (69\% secondary, 59\% primary). Around one third of schools had teachers who had taken the one term course the Infolink Information Literacy Skills Module from the Centre for Information Studies at Auckland College of Education (Infolink) (36\% of secondary schools and 30\% of primary schools). Other types of professional development involved were a National Library seminar (47\% and $25 \%$ respectively) and other seminars (37\% and $30 \%)$.

The percentages taking a National Library seminar findings are consistent with those from a survey of random samples of schools in 2000 as part of the client satisfaction survey programme which found that around one third of schools had received advice or information from advisory services on three aspects of information skills. These were the place of information skills in the curriculum, establishing an information skills programme, and professional development relating to information literacy for teaching staff. Over half the schools said they had increased their skills and knowledge about information literacy to at least some extent as a result of advice/information from the National Library.

The percentages taking a relevant National Library seminar are also consistent with figures from the survey of National Library advisers and centre managers (Slyfield, 2000). Advisers estimated that during 1998 and 1999, approximately 900 schools, representing approximately one third of schools, had participated in 800 professional development activities relating to information literacy/skills, such as workshops, seminars, courses, and network meetings, throughout the country. About $40 \%$ of these had information literacy/skills as their main focus.

\footnotetext{
${ }^{2}$ For a summary of the information relating to information literacy from the three reports on the evaluation of the Focus Programme, see Slyfield, 1999.
} 


\section{Table 8}

\section{Percentage of Teachers with Related Professional Development $(\%$ of} $\underline{\text { Schools) }}$

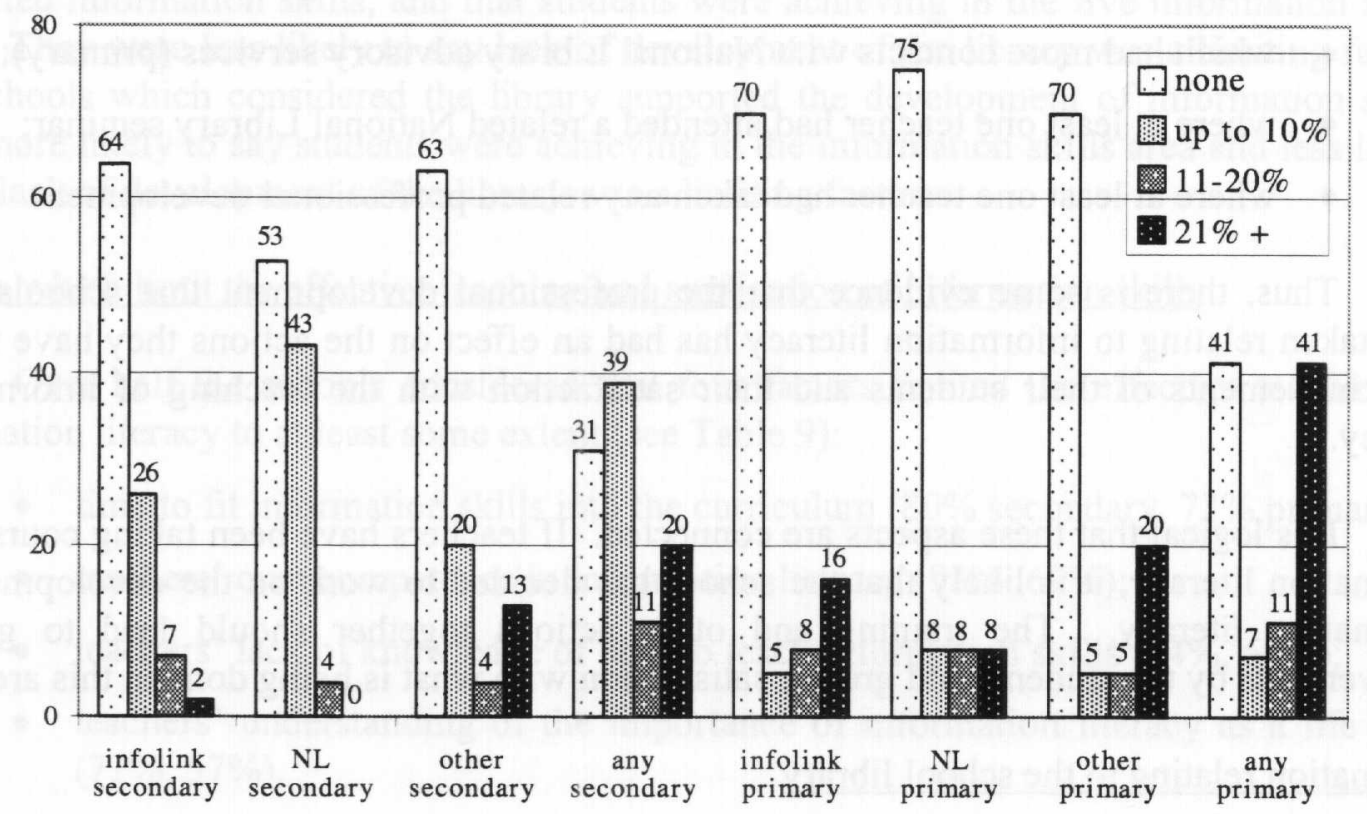

Generally, only a small percentage of the teachers within each school were involved. Ninety percent of secondary schools and $75 \%$ of primary schools indicated that less than half their teachers had taken some form of professional development relating to information literacy.

We would not therefore expect a strong relationship between professional development and responses to other questions such as school-wide actions taken, achievement, and satisfaction with various aspects.

However, schools where teachers had taken relevant professional development were more likely to:

- Have taken more actions (all actions for primary; actions relating to library for secondary);

- Be using the Action Learning model (schools taking Infolink Information Literacy Skills Module (Infolink) for secondary, each type of professional development for primary);

- Consider students were achieving to a greater extent;

- Be satisfied with various aspects of teaching information skills (primary only).

Primary schools which had participated in the Focus Programme tended to be working on more actions relating to information literacy than the other schools and tended to consider students were achieving to a greater extent. 
Schools which were more likely to have been working on clarifying the role of the library and including a goal or objective about information literacy in the school/library strategic plan were schools:

- which had participated in the National Library Focus Programme;

- which had more contacts with National Library advisory services (primary);

- where at least one teacher had attended a related National Library seminar;

- where at least one teacher had taken any related professional development.

Thus, there is some evidence that the professional development that schools have undertaken relating to information literacy has had an effect on the actions they have taken, the achievements of their students and their satisfaction with the teaching of information literacy.

It is logical that these aspects are connected. If teachers have been taking courses on information literacy, it is likely that the school has decided to work on the development of information literacy. The training and other actions together should lead to greater achievements by the students and greater satisfaction with what is being done in this area.

\section{Information relating to the school library}

This section draws together information from throughout the questionnaire which refers specifically to the school library.

A majority of schools had clarified the role of the library collection in supporting the development of information literacy and included a goal or objective relating to information skills in the school/library strategic plan.

Almost all the secondary schools and $74 \%$ of primary schools were very satisfied or satisfied with their school library supporting the development of information literacy.

Secondary schools were more likely than primary schools to have taken the two actions relating to the school library and were more satisfied with their school library supporting the development of information literacy. Primary schools were more likely to consider factors limiting the development of information literacy to be those involving the school library:

- lack of qualified staff in the library ( $53 \%$ primary, $35 \%$ secondary);

- lack of development of school library and information services $(52 \%, 37 \%)$.

These findings probably reflect the greater percentage of secondary schools with librarians $-53 \%$ compared with $6 \%$ of primary schools (Slyfield, in preparation).

A survey of random samples of secondary and primary schools about their school libraries (Slyfield, in preparation) found that a majority of schools gave the school library a rating of very well or well in how it met the needs of students for resources in information skills ( $83 \%$ secondary, $73 \%$ primary). Schools were asked whether they used the library to teach information skills to classes. Around half said some teachers did so $(56 \%, 45 \%)$ and around a quarter said a few teachers did so $(29 \%, 21 \%)$. Primary schools were more likely 
than secondary schools to say all teachers did this (30\% compared with $12 \%$ ). Three percent of each group said no teachers used the library for this purpose.

Schools which had clarified the role of the library were more likely to say the library supported information skills, and that students were achieving in the five information skills areas. They were less likely to say lack of development of the library was a limiting factor. The schools which considered the library supported the development of information skills were more likely to say students were achieving in the information skills area and less likely to say lack of development of the library was a limiting factor.

\section{Factors which limit the effective teaching and application of information skills}

Over half the schools considered that four factors limited the effective teaching of information literacy to at least some extent (see Table 9):

- time to fit information skills into the curriculum ( $80 \%$ secondary, $73 \%$ primary);

- teachers' own competence in information literacy $(83 \%, 69 \%)$;

- teachers' lack of knowledge of how to teach information skills $(84 \%, 60 \%)$;

- teachers' understanding of the importance of information literacy as a life skill $(71 \%, 57 \%)$.

Primary schools were more likely to consider limiting factors to be those involving the school library:

- lack of qualified staff in the library (53\% primary, 35\% secondary);

- lack of development of school library and information services (52\%,37\%).

Thus there seemed to be a need for professional development relating to information literacy and for well-developed school libraries including staffing.

\section{Table 9}

\section{Factors which limit the Effective Teaching and Application of Information}

Skills (\% of Schools to a great extent or some extent)

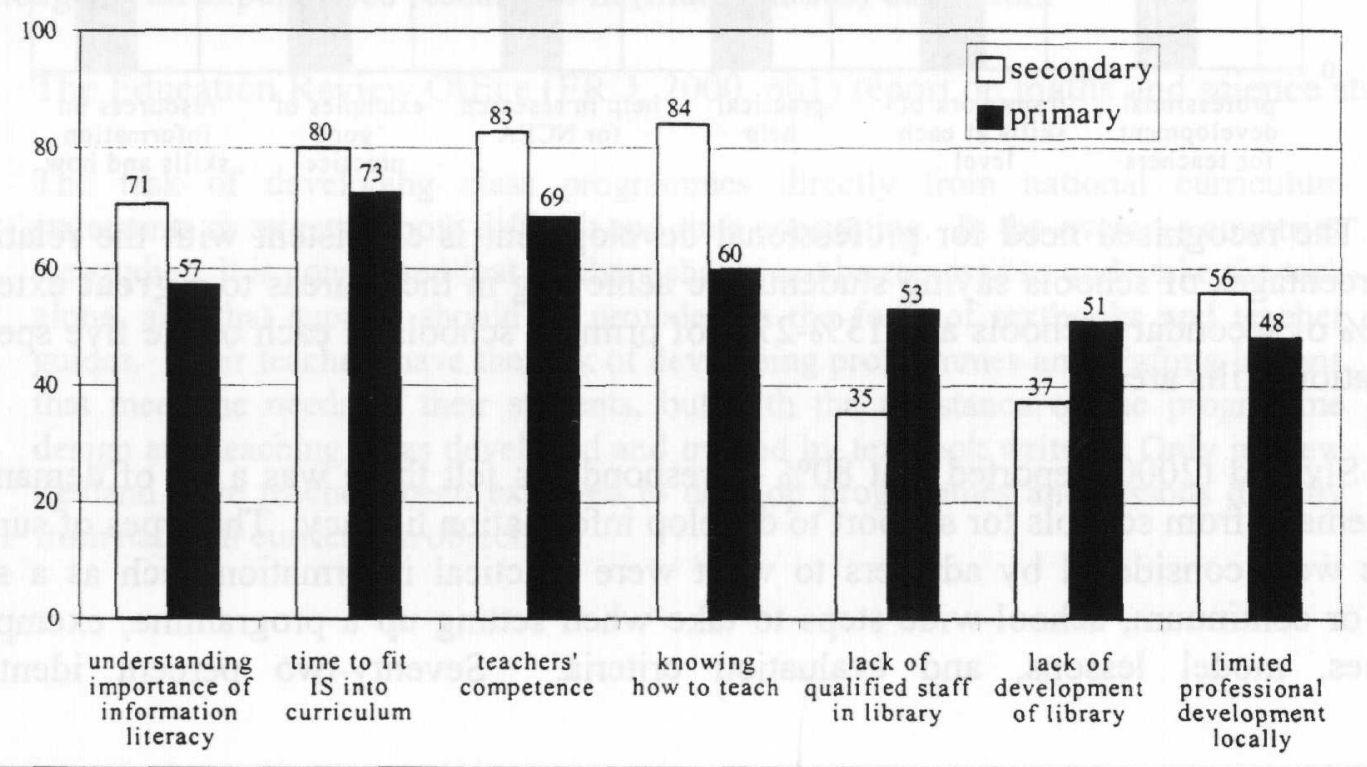

Inspiring connections: Learning, libraries \& literacy 


\section{What is Important in Furthering the Development of Information Skills?}

Almost all respondents ( $90 \%$ to $99 \%$ ) considered five of the six types of possible help to be very important or important in furthering the development of information skills in their school (see Table 10). (The sixth item referred to the National Certificate of Educational Achievement (NCEA) qualification which is not relevant to primary schools.)

Around $70 \%$ of each group of schools considered teacher professional development in understanding information skills and how to include them in the teaching programme to be very important. Other sources of help which were most likely to be rated very important were:

- Framework or template of skills at each level of the curriculum which schools can adapt;

- Practical help such as examples of model lessons, ideas for activities, strategies, exemplars, evaluation criteria;

- Specific resources on information skills and how to teach them.

\section{Table 10}

\section{Furthering the Development of Information Skills in your School $(\%$ of $\underline{\text { Schools Rating very important) }}$}

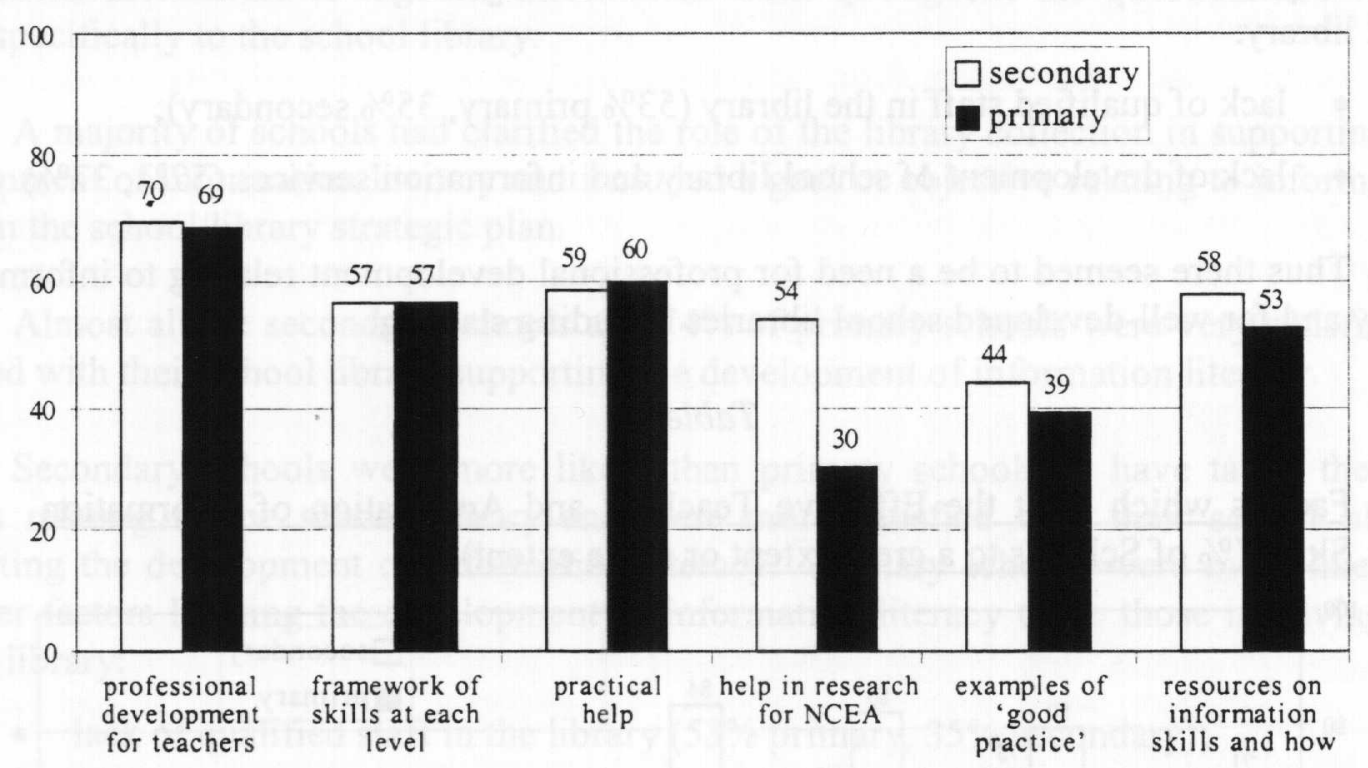

The recognised need for professional development is consistent with the relatively low percentages of schools saying students are achieving in these areas to a great extent $6 \%-17 \%$ of secondary schools and $13 \%-27 \%$ of primary schools in each of the five specific information skills areas.

Slyfield (2000) reported that $80 \%$ of respondents felt there was a lot of demand or some demand from schools for support to develop information literacy. The types of support schools were considered by advisers to want were practical information such as a skills matrix or continuum, school-wide steps to take when setting up a programme, exemplars, resources, model lessons, and evaluation criteria. Seventy-two percent identified 
professional development as one area where schools could take actions to bring about information literacy. Areas suggested were a school-wide cross-curriculum approach, awareness raising, and models of information literacy. Four respondents said that the role of the school library in supporting information literacy needed to be recognised and the library developed to do this. Eighty-six percent of respondents suggested a role for the National Library in terms of professional development.

Brown (1999) also recognised the need for professional development in information literacy and the importance of school libraries, "There are many factors that are involved in the development of students' information literacy. But schools can take responsibility for two main contributors to student achievement. Further professional development of teachers is required. Through such development teachers would develop greater ability to provide the modeling, instruction, and activities that students need to develop their information literacy. Schools will probably need to invest more in creating information-rich environ-ments in which their students can practice their information skills."

These sources of help could be provided through a combination of professional development and specific resources. A specific resource on information literacy would be one way of providing help for those schools which felt the effective teaching of information skills was limited by the professional development opportunities available locally $(56 \%$ secondary, $48 \%$ primary to at least some extent). Small schools and rural schools were more likely than other schools to consider this a limiting factor.

In addition, there seems to be support from other curriculum areas for the idea that teachers need more guidance on developing class programmes.

For example, the report of the mathematics and science taskforce (1997, p4) noted that "The Taskforce was unanimous that 'hands-on' materials for teachers to use are first priority. There is a need to translate the ideals and requirements of the curriculum into practical activities which teachers can use in classrooms." ... "Strategies for helping classroom teachers relate the use of the resource to their own practice, are essential." ... "It is ... important that any recommendations made by this taskforce are pragmatic and are based on the realities of the current situation in schools, and not on idealistic notions of teachers' ability to invent rich activities by themselves and teach them with the pedagogical knowledge of an experienced researcher in (mathematics) education."

The Education Review Office (ERO, 2000, p61) report on maths and science states:

The task of developing class programmes directly from national curriculum statements or targets is both difficult and time consuming. In the overseas countries we studied, it is considered that teachers should not be required to undertake the task alone, and that support should be provided in the form of textbooks and teacher guides. Their teachers have the task of developing programmes and crafting lessons that meet the needs of their students, but with the assistance of the programme design and teaching ideas developed and trialled by textbook writers. Only in New Zealand have teachers been expected to develop programmes and lessons directly from national curriculum objectives. 
ERO says that investigation and action are required to address "the resources and materials, including specific teacher guides, textbooks and other curriculum-related resources and teaching equipment, available as a matter of course for teachers to implement the mathematics and science curricula" (p104), so that they result in "support for teachers in understanding and implementing the curriculum through increased and improved curriculum-related resources, professional development and readily accessible expert advisory services that are known to be effective" (p105).

A report on implementing the technology curriculum (Chamberlain et al, 1999, p13) noted "schools have a strong desire for guidance, and materials and resources to support the curriculum". Around $80 \%$ of schools or more said curriculum resource materials and assessment guidelines would help teachers implement the curriculum.

The Report of the Literacy Taskforce (Ministry of Education, 1999) stated " The taskforce agreed that teachers need more assistance than is currently available through the materials provided. This does not mean step-by-step instructions for teachers to follow but more detail to help them select and use appropriate instructional approaches and strategies, ..." (p12). The taskforce suggested a comprehensive professional development package using media such as videos and printed material, which could be used either independently or as part of a formal professional development programme.

\section{CONCLUSION}

The research indicates that most schools are working on various aspects of teaching information skills and that their students are developing these information skills to at least some extent. However, schools seem to recognise that there is still some way to go.

The research showed a strong need for professional development for teachers and for resources relating to information literacy. It is particularly important that these cover the place of information skills in the teaching programme, a framework of skills at each level, and practical help for teaching and evaluating information skills.

The next step seems to be for the key agencies involved to clarify the actions each agency needs to take in order that teachers get the support they have indicated they need.

\section{REFERENCES}

Brown, G. (1997). Information skills in the New Zealand curriculum: A blueprint for education? Paper presented at New Zealand Association for Research in Education (NZARE) Conference, Auckland.

Brown, G. (1999). Information skills: How information literate are New Zealand children? Paper presented at New Zealand/Australia Association for Research in Education (NZARE/ AARE) Conferesce, Melbourne.

Chamberlain, M., Weenink, M., \& Renwick, M. (1999). Schools' progression towards implementation of technology in the New Zealand curriculum: A summary of results of 1998 research, Research Bulletin, No 10, Wellington: Ministry of Education. 
Crooks, T., \& Flockton, L. (1997). Information skills: Assessment results 1997. National Education Monitoring Report 7. Dunedin: University of Otago, Educational Assessment Research Unit.

Crooks, T., \& Flockton, L. (1999), Graphs, tables and maps: Assessment results 1999. National Education Monitoring Report 15. Dunedin: University of Otago, Educational Assessment Research Unit.

Eisenberg, M. B., \& Berkowitz, R. E. (1998). The Big6 skills information problem - solving approach to library and information skills instruction.

Gawith, G. (1987), Information alive!: Information skills for research and reading. Auckland:. Longman, Paul.

McAlpine, D., Poskitt, J., \& Bourke, R. (1997). Assessment for better learning, final report to Ministry of Education, quoted in Assessment for success in primary schools, Green paper, Ministry of Education, May 1998.

Moore, P. (1998). Teaching information problem solving in primary schools. Wellington: Ministry of Education.

Moore, P. (1999). Primary school children's interaction with library media: Information literacy in practice. Available: http://www.teacherlibrarian.com/moore27,3.html.

Moore, P. (2000). Towards information literacy: One school's journey. Wellington: New Zealand Council for Educational Research.

National Library of New Zealand (1998). Towards the $21^{\text {st }}$ Century. Wellington: National Library.

New Zealand Education Review Office (1999). Student assessment: Practices in primary schools, Wellington: Education Review Office.

New Zealand Education Review Office (2000). In Time for the Future: A Comparative Study of Mathematics and Science Education. Wellington: Education Review Office.

New Zealand Government (2001). Workforce 2010. Wellington.

New Zealand Ministry of Education (1993). The New Zealand curriculum framework. Wellington: Learning Media.

New Zealand Ministry of Education (1993). Science in the New Zealand curriculum. Wellington: Learning Media.

New Zealand Ministry of Education (1994). English in the New Zealand curriculum. Wellington: Learning Media.

New Zealand Ministry of Education (1997). Social studies in the New Zealand curriculum. Wellington: Learning Media.

New Zealand Ministry of Education (1997). Report of the Mathematics and Science Taskforce. Wellington: Ministry of Education.

New Zealand Ministry of Education (1998). Assessment for success in primary schools. Green Paper, Wellington: Ministry of Education.

New Zealand Ministry of Education (1999). Report of the Literacy Taskforce. Wellington: Ministry of Education.

Reid, N., Croft, C., \& Jackson, P. (1969). Progressive achievement tests. Wellington: New Zealand Council for Educational Research.

Slyfield, H. (1999). National Library services to schools: Use, assessment and outcomes. Wellington: National Library.

Slyfield, H. (2000). Information Llteracy: Survey of National Library advisers and centre managers. Wellington: National Library.

Slyfield, H. (2001, in preparation). School libraries in New Zealand. Wellington: National Library. 